\title{
Obsessed maniacs and clairvoyant oracles: empirically validated patterns of entrepreneurial behavior
}

\author{
Elias G Carayannis* and McDonald R Stewart
}

\footnotetext{
* Correspondence: caraye@gwu.edu Department of Information Systems and Technology Management, The George Washington University School of Business, $2201 \mathrm{G}$ Street, N. W., Funger Hall 601, Washington, DC 20052, USA
}

\begin{abstract}
Diverse and complex challenges in new venture formation demand rare and exceptional entrepreneurial acumen, particularly in technology-driven environments where disrupted markets amplify the factors and magnitude of uncertainty and risk. The successful technology entrepreneur (term of art for Strategic Knowledge Arbitrage and Serendipity (SKARSE ${ }^{\mathrm{TM}}$ ) enactors) is focused yet flexible, demonstrating relentless intensity of purpose while adapting that purpose under changing conditions. The distinguished entrepreneur accurately predicts events and conditions in advance for superior strategic positioning. We find that two terse descriptors - obsessed maniacs and clairvoyant oracles - encapsulate critical attributes conducive to superlative entrepreneurial posture, propensity, and performance to anticipate and recognize challenges and convert them into opportunities. In so doing, the entrepreneurs leverage strategic knowledge serendipity factors and practice strategic knowledge arbitrage competences. From the pre-market perspectives of R\&D and innovation management through successful marketing and commercialization of engineered innovations, technology foresight and forecasting pivot on the entrepreneur's unrelenting persistence to pursue a vision and unclouded prescience of exactly what vision to pursue. To investigate our premise, we conduct comprehensive surveys and interviews with 33 founding entrepreneurs, comparatively analyzing their experiences against complementary data sources to develop personal profiles of critical attributes and behavioral characteristics. Employing qualitative analytic techniques, we find the data rich in empirical evidence to support a perspective of entrepreneur as obsessed maniac and clairvoyant oracle, plus many other intrinsic characteristics of personality, motivation, intention, and action that constitute the entrepreneurial actor.
\end{abstract}

Keywords: Competitiveness, Creativity, Entrepreneurship, Innovation, Knowledge partnership, Robust competitiveness, Sustainable entrepreneurship, Start-up, Sustainable growth, Technology adoption and diffusion

\section{Background}

In the realm of social sciences, much business and economic theory is devoted to the construction of frameworks that describe complex organizational systems: the group, the firm, the industry, and the institution. Underlying these interdependent and concentric layers of business structure are individuals whose actions antecede and propel the formation of new business organizations. The precursive enactor is termed Entrepreneur. Each starting with a blank page, an idea, and the urge to proceed, individual entrepreneurial

\section{Springer}

(c) 2013 Carayannis and Stewart; licensee Springer. This is an Open Access article distributed under the terms of the Creative Commons Attribution License (http://creativecommons.org/licenses/by/2.0), which permits unrestricted use, distribution, and reproduction in any medium, provided the original work is properly cited. 
initiatives create organizations (firms) that spawn industries which in turn give rise to institutions. Complex business and economic systems are created, revised, destroyed, and replaced by the successive and evolutionarily execution of entrepreneurial ambition.

Entrepreneurship encompasses a unique place in the spectrum of business management: maneuvering from zero to something - intentionally a functioning and preferably economically viable organization - and ideally one that can sustainably perform and thrive, even in the later absence of the founding entrepreneur after he or she has moved on. Multi-faceted challenges in new venture formation demand rare and exceptional skills and qualities of an entrepreneur, particularly in technology-driven environments where the forecasting and management of R\&D and innovation amplify the factors and magnitude of uncertainty and risk. An entrepreneur's ability to predict the future or in fact to anticipate and shape via Strategic Knowledge Arbitrage (enlightened insights) and Serendipity ("happy accidents") $\left(\right.$ SKARSE $\left.^{\mathrm{TM}}\right)$ competences (Carayannis 2008a, b; Carayannis et al. 2011), or a relentless pursuit of such a self-assured vision, demands thinking and learning - indeed higher order learning and more specifically learning-to-learn and learning-to-learn-how-to-learn (Carayannis 2000a, 2000b, 2001, 2008a, 2008b, 2009, 2012; Carayannis and Sipp 2010a; Carayannis and Alexander 2002; Carayannis et al. 2006, 2011; Carayannis and Provance 2007; Carayannis and Kaloudis 2008) that is highly specialized and to a great extent aberrant because of the unpredictable and precarious proposition of starting a new business venture, particularly tenuous in technology markets, where competitive and environmental forces are markedly turbulent and stochastic. The successful technology entrepreneur acts as firebrand of cultural and socio-technical evolution in identifying and unlocking economic opportunities embedded in emerging technologies and kindling the markets in which these technologies commercially proliferate. In short, the technology entrepreneur in our emerging and empirically grounded theory behaves as SKARSE enactor.

Of necessity, the entrepreneur is extremely focused yet flexible, demonstrating a relentless intensity of purpose while adapting that purpose with nimble dexterity as events unfurl and conditions change. Moreover, the distinguished entrepreneur will accurately predict events and conditions before they occur to permit strategic positioning of the venture for optimal advantage. We find that two terse descriptors - obsessed maniacs and clairvoyant oracles $(O M C O)$ - encapsulate the critical attributes most conducive to superior entrepreneurial performance. This paper examines the OMCO factors that contribute to the new venture's fate, attributable to the entrepreneur as enactor of endogenous economic change and hopefully growth, independent of or in spite of myriad market challenges.

\title{
Theoretical background
}

Discovery consists of looking at the same thing as everyone else and thinking something different.

\author{
-Albert Szent-Györgyi (Nobel Prize Winner)
}

\section{The drive for innovation}

Invention is a singular event, born of science, research, discovery, creativity, and serendipity; invention does not always impact or influence technology. Innovation is an interactive 
process; it is the cultivation of knowledge, materials, and methods into economic practice for improved competitive advantage, born of engineering, development, customization, evolution, plus science, research, discovery, creativity, and serendipity. Innovation is not just invention but an economically viable adaptation, improvement, or application of a technology via the exploration and exploitation (Carayannis et al. 1998) of 'happy accidents' and 'enlightened insights' (SKARSE ${ }^{\mathrm{TM}}$ in action) (Carayannis 1992, 1993, 1994a, b, c, 1998, 1999a, b, 2000a, b, 2001, 2004, 2008a; Carayannis and Alexander 1999, 2002, 2004; Carayannis and Campbell 2006, 2009; Carayannis and Chanaron 2007; Carayannis and Gonzalez 2003; Carayannis et al. 2003, 2006, 2007; Carayannis and Juneau 2003; Carayannis and Sipp 2006; Carayannis and von Zedtwitz 2005; Carayannis and Ziemnowicz 2007; EG Carayannis, 1998-2011, unpublished lecture notes; EG Carayannis, 2002-2009, unpublished lecture notes; EG Carayannis and MR Stewart, 2007-2011, unpublished lecture notes).

Florida and Kenney (1990) describe invention as a technical breakthrough, while innovation is a commercial actualization. Hindle and Lubar (1986) view invention as the creative origin of a new process that enables innovation. Innovation in turn has a social, economic, and financial impact. Kline and Rosenberg (1986, pp 285-287) emphasize the recursive nature of the innovative process, discounting the linear model, "one does research, research then leads to development, development to production, and production to marketing," and amplifying the reciprocating roles of science and knowledge in the innovation process, "...not only that innovation draws on science, but also that the demands of innovation often force the creation of science." The products of scientific research in the laboratory and technological innovation in commercial markets form a feedback loop, with each driving the other, derived from each other.

Afuah (2003) confirms that invention is the creation a new possibility, but innovation develops that possibility to usefulness or marketability, "the use of new knowledge to offer a new product or service that customers want. It is invention + commercialization.". Carayannis and Gonzalez (2003) offer this consolidated interpretation of innovation as a function of the creative collective of the market, both supply side and demand side:

Innovation is a word derived from the Latin, meaning to introduce something new to the existing realm and order of things or to change the yield of resources as stated by J. B. Say quoted in Drucker (Drucker 1985).

In addition, innovation is often linked with creating a sustainable market around the introduction of new and superior product or process. Specifically, in the literature on the management of technology, technological innovation is characterized as the introduction of a new technology-based product into the market:

Technological innovation is defined here as a situationally new development through which people extend their control over the environment. Essentially, technology is a tool of some kind that allows an individual to do something new. A technological innovation is basically information organized in a new way. So technology transfer amounts to the communication of information, usually from one organization to another (Tornazky \& Fleischer, 1990). 
The broader interpretation of the term 'innovation' refers to an innovation as an "idea, practice or material artifact" (Rogers \& Shoemaker, 1971, p. 19) adopted by a person or organization, where that artifact is "perceived to be new by the relevant unit of adoption" (Zaltman et al., 1973). Therefore, innovation tends to change perceptions and relationships at the organizational level, but its impact is not limited there. Innovation in its broader socio-technical, economic, and political context, can also substantially impact, shape, and evolve ways and means people live their lives, businesses form, compete, succeed and fail, and nations prosper or decline.

\section{Dynamics of technology evolution}

The literature on innovation describes several mechanisms in multiple categories whereby the trajectory of a technology S-curve is formed. Carayannis et al. (2003) offer a useful presentation of the forces and influences that define and shape the evolution of technology performance.

At the beginning of an emerging technology life cycle, there is a discovery or invention that shows promise in addressing a social need or delivering a new technological capability. Emergence and early growth accelerate from this outset to maximum growth at inflection, which is shaped by the interplay of two forces: technology push (also called supply push) and market pull (also called demand pull). With technology push, producers devise and introduce new technology to the market, showcasing their 'better mousetrap', making a new solution available before demand is created. With market pull, consumers express unfulfilled wants and needs, urging for a better way of doing things, creating economic incentive for suppliers to provide a new solution.

Later growth, diminishing after the maximum growth at inflection and leveling off at maturity (ultimately dwindling into obsolescence), is also shaped by the interplay of two converse forces antipodal to those in earlier operation: technology pull and market push (Carayannis et al. 2003; EG Carayannis, Carayannis 1998-2011, unpublished lecture notes; EG Carayannis and MR Stewart, 2007-2011, unpublished lecture notes). With technology pull, producers cannibalize old technology investments to sustain their returns and suppress disruptive innovations for as long as possible, perhaps until the fundamental physics upon which the technology is built reaches its natural limit. With market push, industry or regulatory standards, market alliances, and other societal constraints suppress incremental improvements. Notwithstanding the persistence of efforts to extend the plateau of technology maturity, obsolescence of the earlier technology is inevitable, effectively occurring when the technical performance per dollar (or the cumulative adoption) of the disruptive, radical newer technology exceeds the level of the older technology (i.e., the new $\mathrm{S}$-curve crosses above the prior S-curve). Once these curves cross, there is a cascade of additional investment in the new technology, with resultant economies of scale and market adoption, steepening the emerging curve while hastening the decline and obsolescence of the mature technology.

The critical determinant of emergence and growth of a technology is innovation. Innovation is the cultivation of knowledge, materials, and methods into economic practice for improved competitive advantage. It is the transformation of an invention generated by scientific activity into a socially usable product, changing economics from supply terms to demand terms and increasing the value and satisfaction obtained from resources by the consumer. To wit, innovation is the market actualization of better ideas (Carayannis 2009; 
Carayannis et al. 2003; Stewart 2011; EG Carayannis, 1998-2011, unpublished lecture notes; EG Carayannis and MR Stewart, 2007-2011, unpublished lecture notes).

\section{The role of the entrepreneur in technology venture formation}

An entrepreneur is an agent of change: the seminal actor who conceives and implements a new business venture, impelling a new economic entity from ideation to functional reality. The entrepreneur assumes the risks of forming a business or enterprise, organizing and managing every facet of its emergence.

T Åstebro and P Thompson (2007, Does it pay to be a jack of all trades?, unpublished manuscript) affirm that the entrepreneur must be a business jack-of-all-trades with substantive technical savvy and a project manager extraordinaire to also integrate systems in the 21st century commercial complexity. Interpreting Schumpeter (1942), entrepreneurship is the recognition and exploitation of opportunity - a recombinant or novel deployment of resources - the envisioning, planning, and implementing of mechanisms to create economic opportunity. Entrepreneurship seeks to shift the established means of economic creation and control, strategically reappointing economic resources from established pathways to innovative pathways (Stewart 2011, page 99).

Drucker (1985, p. 21) underscores Say's most famously quoted adage, "The entrepreneur shifts economic resources out of an area of lower and into an area of higher productivity and greater yield." This is achieved through technological innovation, the "specific instrument of entrepreneurship." (Drucker 1985, p. 30).

In the context of the Mode 3 Innovation Ecosystem (Carayannis and Campbell 2006, 2009) and the C3 construct of co-opetition, co-specialization, and co-evolution (Carayannis 2004, 2008a, b; Carayannis and Gonzalez 2003; Carayannis and von Zedtwitz 2005; Carayannis and Campbell 2006, 2009). Carayannis (2008b, 2009) discusses heterogeneity dynamics, pertaining to the diversity of factors underpinning the inputs, processes, and outputs which govern innovation and adaptation. According to Carayannis (2008b, 2009) (see Figure 1),

Input, process and output heterogeneity deals with the issue of value creation in a socioeconomic context. ..:

- Input heterogeneity refers to the variety and diversity of the key inputs to economic activity, namely, land, labor, capital, technology and entrepreneurship as identified by Adam Smith, Ricardo, and Joseph Schumpeter among others. Intrinsic in all these inputs is knowledge, which has been increasingly the key source of value adding of most human endeavors.

- Process heterogeneity reflects the variety and diversity intrinsic in the ways that the key inputs to economic activity are leveraged, allocated, re-combined and re-created as part of the processes of technology innovation and entrepreneurship aiming at the maximization of value added.

- Output heterogeneity reflects the diverse ways and means that the value added of economic activity combining and leveraging the key inputs discussed earlier, is captured and exploited, namely, number and size of firms, firm performance, market concentration, number and rate of renewal of products and services, as well as public-private sector partnerships structure and performance, to name a few. 


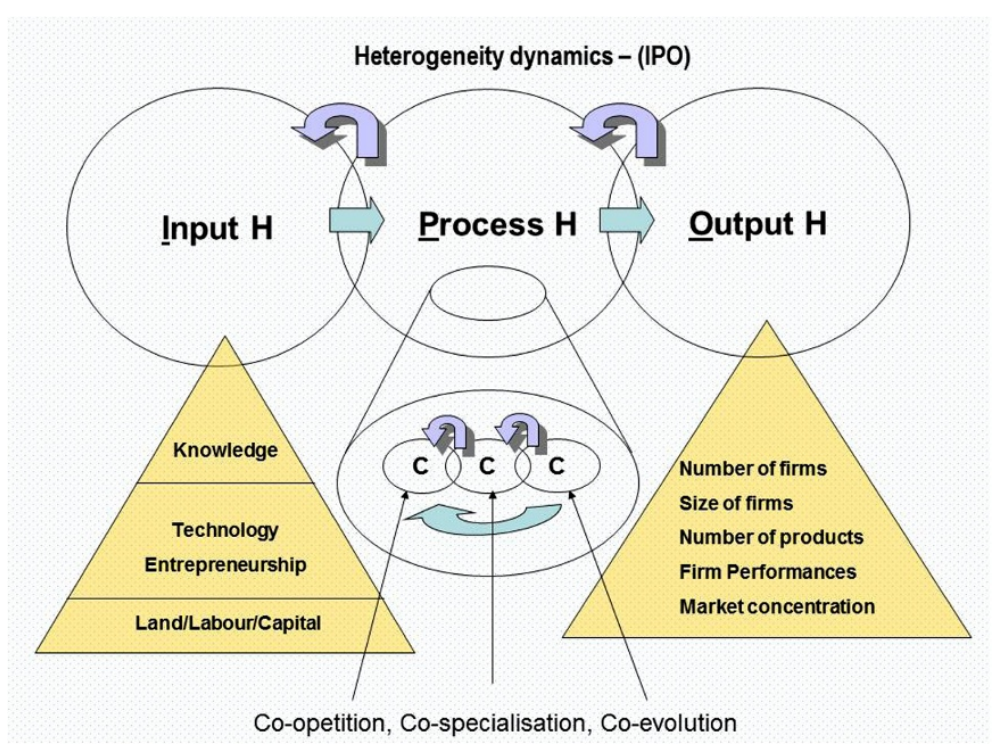

Reprinted from Carayannis (2008b, 2009)

Figure 1 Heterogeneity dynamics: co-opetition, co-evolution, and co-specialization.

The significance of these heterogeneity dynamics to the role of the technology entrepreneur in venture formation leads to two additional crucial theoretical constructs: sustainable entrepreneurship and robust competitiveness (Carayannis 2008b, 2009):

Sustainable entrepreneurship: the creation of viable, profitable and scalable firms that engender the formation of self-replicating and mutually enhancing innovation networks and knowledge clusters leading towards what we call robust competitiveness. Robust competitiveness: a state of economic being and becoming that affords systematic and defensible 'unfair advantages' to certain entities. It is built on mutually complementary and reinforcing low-technology, medium-technology and hightechnology public-sector and private-sector organizations (government agencies, private firms, universities and non-governmental organizations).

The key success factors for sustainable entrepreneurship - one of the major pillars of robust competitiveness - are diagrammed to show the micro-level stages, drivers, and determinants of heterogeneity dynamics at Figure 2.

An entrepreneur's ability to assess innovative economic opportunity amounts to an aptitude for predicting the future (or this person's firm belief in possessing such ability). Relentless, self-confident pursuit of this vision represents specialized and exceptional thinking, learning, and decision-making. These factors are the distinguishing qualities of entrepreneurs that Carayannis (1998-2011, unpublished lecture notes; Carayannis and Gonzalez, 2003) terms obsessed maniacs and clairvoyant oracles.

\section{Purpose of this research}

This research is part of a larger qualitative study in grounded theory building. The explicit objective of this component is to identify and illuminate the intrinsic characteristics of 


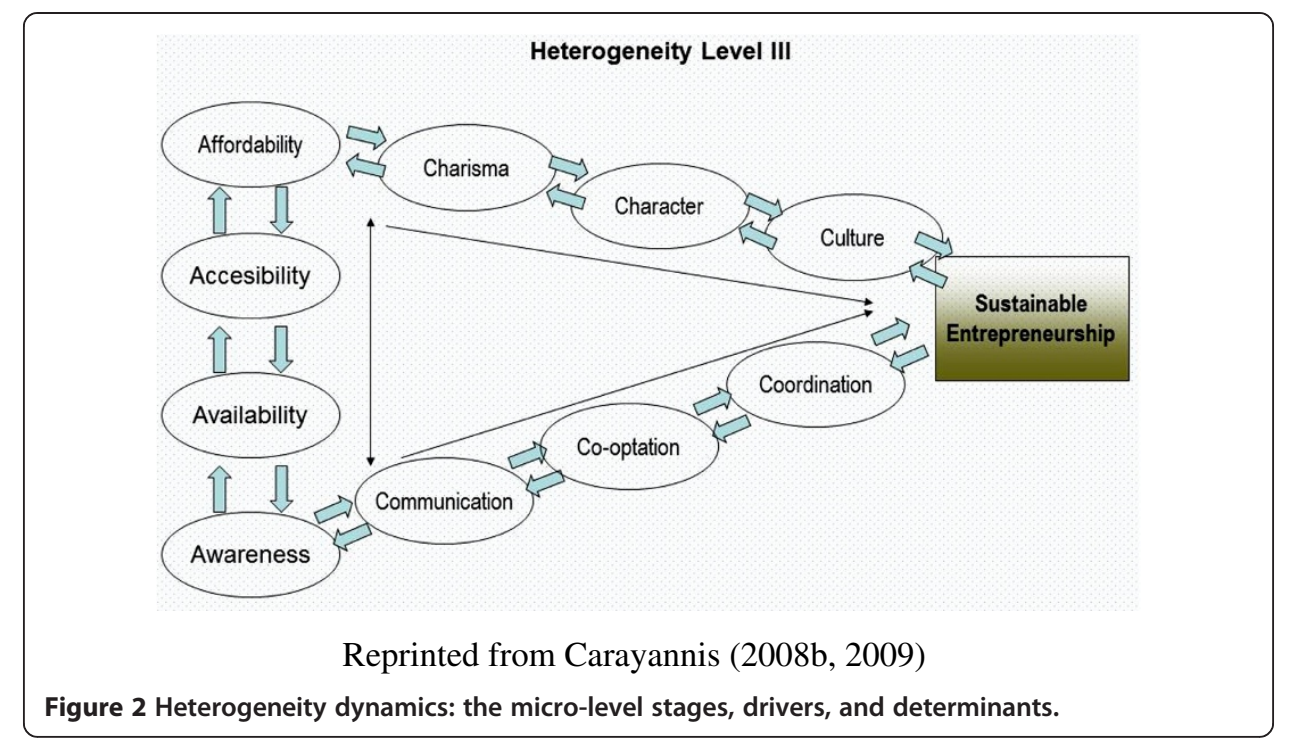

entrepreneurial actors and their actions, building and enriching a common vocabulary within the specifically narrow emerging field of Technology Entrepreneurship, and informing the scholarly framework of Technology Entrepreneurship toward a unifying grounded theory.

\section{Results and discussion}

Assimilating a grounded theory of the technology entrepreneur

This research attempts to establish some critical factors attributable to the entrepreneur as the originator of new organizations of economic creation and control, specifically investigating what defines and distinguishes an entrepreneur. The analysis and findings from the data processing methodology permits the remolding of the data into an interpreted grounded theory of the entrepreneur, summarized in Tables 1 and 2.

\section{Evaluation of the findings}

By the qualitative nature of the origin of grounded theoretical framework, none of the theme components are afforded any quantitative value, neither relative nor absolute. The grounded theory exhibits that the reported elements are observed and interpreted to be factors salient to the nature of the entrepreneurs. No determination can be made of the degree to which each factor operates in modeling the mechanisms of technology entrepreneurship. This is a limitation of this research, but deeper qualitative interpretation is feasible.

\section{Assessment of the intrinsic characteristics of entrepreneurial actors and actions}

Applying the grounded theory against the research objective, we pose two questions of the intrinsic characteristics of entrepreneurial actors and actions, as addressed below:

1) What are the qualities and attributes that characterize an entrepreneur in terms of technology venturing? 
Table 1 Interpreted grounded theory of the entrepreneur: entrepreneurial constitution what the entrepreneur might have

\begin{tabular}{|c|c|c|}
\hline Thematic dimension & Thematic code category & Theme component \\
\hline \multirow{21}{*}{$\begin{array}{l}\text { Constitution: what the technology } \\
\text { entrepreneur might have }\end{array}$} & \multirow{9}{*}{ Personal characteristics } & Knowledge, experience \\
\hline & & Creativity, innovativeness \\
\hline & & $\begin{array}{l}\text { Natural salesmanship, ability to sell idea, } \\
\text { persuasiveness }\end{array}$ \\
\hline & & Exceptional credibility, reputability \\
\hline & & Intelligence, analytical ability \\
\hline & & $\begin{array}{l}\text { Knowledge of what he or she does not } \\
\text { know }\end{array}$ \\
\hline & & $\begin{array}{l}\text { Knowledge of what is outside personal } \\
\text { span of control }\end{array}$ \\
\hline & & Egocentrism \\
\hline & & Aggressiveness \\
\hline & \multirow{5}{*}{$\begin{array}{l}\text { Actively positioning } \\
\text { for opportunity }\end{array}$} & Resourcefulness \\
\hline & & Vision, seeing what others do not see \\
\hline & & Innate entrepreneurial personality, intuition \\
\hline & & Idealism, entrepreneurial upbringing \\
\hline & & Adaptability, versatility \\
\hline & Experiencing good fortune & Happy accidents \\
\hline & \multirow[t]{4}{*}{ Drive and perseverance } & Workaholism \\
\hline & & Personal ambition \\
\hline & & Perfectionism, control issues \\
\hline & & $\begin{array}{l}\text { Exaggerated optimism, passion, excitement, } \\
\text { loving what he or she does }\end{array}$ \\
\hline & Risk orientation & Risk-affinity \\
\hline & Ethics & Integrity \\
\hline
\end{tabular}

The answer to this research question is drawn from the theme components from the dimensions presented at Tables 1 and 2: Constitution and Behaviors. These 46 themes emerged from the aggregated data analysis to denominate the spectrum of qualities and attributes of technology entrepreneurs that could be observed or reported in the findings from their profile and interview data. One limitation of this research is that data saturation cannot be affirmed; it is unknowable how many additional qualities and attributes might be ascribed given additional data, but this research supports these 46 .

2) When, how and why are the specific attributes of "obsessed maniac" and "clairvoyant oracle" (Carayannis and Gonzalez 2003; EG Carayannis, 1998-2011, unpublished lecture notes) observed?

To address this inquiry requires the construction of a linkage between the grounded theory interpreted from the findings and the meanings ascribed to the terms drawn from the literature, 'obsessed maniac' and 'clairvoyant oracle'. Beginning with an abundance of dictionaries and looking to each word alone, the researcher must impose interpretations on these resources, as well. Assimilating several sources, the term 'obsessed' might be best described as 'possessing a compulsive preoccupation with a fixed idea'. This researcher 
Table 2 Interpreted grounded theory of the entrepreneur: entrepreneurial behaviors what the entrepreneur might do

\begin{tabular}{|c|c|c|}
\hline Thematic dimension & Thematic code category & Theme component \\
\hline \multirow{24}{*}{$\begin{array}{l}\text { Behaviors: what the technology } \\
\text { entrepreneur might do }\end{array}$} & \multirow{3}{*}{ Personal characteristics } & Makes something \\
\hline & & $\begin{array}{l}\text { Knows what is not known and does } \\
\text { something about it }\end{array}$ \\
\hline & & Learns to be an entrepreneur \\
\hline & \multirow[t]{7}{*}{$\begin{array}{l}\text { Actively positioning for } \\
\text { opportunity }\end{array}$} & $\begin{array}{l}\text { Lives in the present, but dreams of the } \\
\text { future }\end{array}$ \\
\hline & & Strategically networks and makes alliances \\
\hline & & $\begin{array}{l}\text { Pursues merger, acquisition, or venture } \\
\text { partnering }\end{array}$ \\
\hline & & $\begin{array}{l}\text { Invests in strategic plans, market targeting, } \\
\text { goal setting }\end{array}$ \\
\hline & & $\begin{array}{l}\text { Invests personal resources in business } \\
\text { idea }\end{array}$ \\
\hline & & Accepts change \\
\hline & & Makes the best of a bad situation \\
\hline & \multirow[t]{6}{*}{ Experiencing good fortune } & Discovers talent \\
\hline & & Finds unexpected market opportunity \\
\hline & & Wings it without a plan \\
\hline & & Gains windfalls \\
\hline & & $\begin{array}{l}\text { Makes his or her own luck scenarios } \\
\text { and goes after them aggressively }\end{array}$ \\
\hline & & $\begin{array}{l}\text { Was rejected or underappreciated } \\
\text { by former employer }\end{array}$ \\
\hline & \multirow[t]{3}{*}{ Drive and perseverance } & Always moves ahead \\
\hline & & Never gives up \\
\hline & & $\begin{array}{l}\text { Is willing to make sacrifices, } \\
\text { endures hardship }\end{array}$ \\
\hline & Risk orientation & $\begin{array}{l}\text { Practices risk management and } \\
\text { risk reduction }\end{array}$ \\
\hline & \multirow[t]{2}{*}{ Fairness, sense of justice, civility } & Believes it is business, not personal \\
\hline & & $\begin{array}{l}\text { Cultivates healthy relationships } \\
\text { within business }\end{array}$ \\
\hline & \multirow{2}{*}{$\begin{array}{l}\text { Personal health and well-being, } \\
\text { relationships - positive impacts }\end{array}$} & Maintains a healthy balance \\
\hline & & Finds family support \\
\hline
\end{tabular}

suggests that a concise connotation of 'maniac' is 'one possessed of an excessively intense enthusiasm, interest, or desire'. 'Clairvoyant' distills to 'having acute intuitive insight or perceptiveness'. An 'oracle' in its most generic connotation is a person who can offer wise counsel or prophetic opinions.

These terms do not seem to apply in their entirety to the majority of research subjects in this study. Themes are found that correspond in varying degree to the theoretical constructs of obsessed maniac or clairvoyant oracle but very infrequently are these attributes all found in the same entrepreneur. Of these suggestive themes, there is also a spectrum of manifestations, such that one entrepreneur's data qualitatively indicate a more extreme degree of one attribute than another, but assessing the degree of thematic factors is beyond the limitations of this study. 
The themes from the Code Book developed in this research that most closely evoke obsession are the following:

- Drive and perseverance - workaholism

- Drive and perseverance - perfectionism, control issues

- Drive and perseverance - difficulty accepting rejection of ideas, stubborn, never giving up

- Personal health and well-being, relationships - negative impacts; neglect of personal friendships/relationships/leisure

The themes that most closely evoke mania are the following:

- Personal characteristics - aggressiveness

- Experiencing good fortune - 'happy accidents'; winging it without a plan

- Drive and perseverance - personal ambition, restless, always moving ahead

- Drive and perseverance - exaggerated optimism, passion, excitement, loving what they do

- Personal health and well-being, relationships - negative impacts; symptoms of anxiety, stress and pressure as part of the job

The terms clairvoyant and oracle are so similar in connotation that they are indistinguishable within the resolution of the thematic findings. The themes that most closely evoke clairvoyant oracle are as follows:

- Personal characteristics - natural salesperson, ability to sell idea, persuasiveness

- Actively positioning for opportunity - vision, seeing what others do not see

- Actively positioning for opportunity - investing personal resources in business idea

- Experiencing good fortune - make your own luck scenarios and go after them aggressively

\section{Exemplars from the Data Book to illustrate obsessed maniacs and clairvoyant oracles}

Selecting passages from the foregoing evocative themes within the Data Book developed in this research, the following interpretive analysis and illustrative quotations provide evidence to support the entrepreneurial descriptors, obsessed maniac and clairvoyant oracle:

\section{Drive and perseverance - workaholism}

One theme related to both drive and perseverance and prevalent among all the data sets is workaholism. The entrepreneur who has contracted with himself or herself to make good on countless promises by positioning for the best opportunities is very likely consigned to fulfill many functional roles in an emerging venture and, at the same, be possessed of the motivation to perform multiple 'full-time' and part-time jobs in parallel, since once the enterprise is put in motion, the rewards for its success are presumably ample and the penalties for its failure abhorrent. Such is the obsessed conviction of the entrepreneurial workaholic. Examples include:

To get as far as we did, I spent a great deal of time and energy, traveling, days away from home, 60-hour work weeks from Sunday evening to Friday night. 
It's so all-consuming-you're spread so thin. At the outset you literally are always working on it, substituting human capital for the thin financial capital-that's why it's called sweat equity. The mind is focused on this one thing. Friends who have not participated in starting a business won't understand and think you are obsessed. You have to be obsessed to build it-you have to be!

McGowan returned home in May, barely a month after the surgery. By July, he was at work half-days. Last month, he returned to his desk full time-"a normal full day," he says, "not those crazy full days" of the past. His energy now is much greater than before his heart attack, his wife reports. In fact, when a physician told her that McGowan probably had a "silent" heart attack years ago and had been working at only about half capacity ever since, she said to herself, "Oh, my God, doctor, if you only knew!" (Cook 1987)

\section{Drive and perseverance - perfectionism, control issues}

The theme of perfectionism and control issues surfaced in many instances among the data sets, concentrating and extending the driven persistence of some entrepreneurial subjects onto those around them, sometimes to an obsessive degree. Some excerpts that exhibit this are as follows:

I tend to be a perfectionist and probably should have released the product sooner.

I always got everything to go the way I thought they should.

This is the most difficult time of my life-I am a doer and I can make people do things, but if I can't I feel I have failed.

Because quality and cleanliness were near obsessions with Kroc (his oft-quoted motto: "If you have time to lean, you have time to clean"), he automated as many operations as possible and instituted rigid training programs at "Hamburger University" for franchise owners, whom he required to manage their own stores. Many who came in contact with Kroc over the years complained of his abrasive manner and large ego, but his insistence on absolute conformity to his ideas was largely the reason for the chain's success. (Davids 1999)

\section{Drive and perseverance - difficulty accepting rejection of ideas, stubborn, immobile}

Difficulty accepting rejection of ideas, stubbornness, and immobility forge another prevalent theme - a sense of single-minded purpose - akin to egocentrism but imposed obsessively on the venture and the others engaged in its formation and operation. The following instances evince the interpretation of this theme:

On day one I had no clue where I was going with this, but I just did not want to quit. I had been in another golf equipment company that went broke, but I couldn't bear to walk away.

It wasn't easy to test ideas dealing with hardware-I went too much on 'gut' about what the market wanted and what we could do technically. Perhaps more market 
research for real testing would have made sense, but ego is a massive fuel and a real bad drug. The market can call your baby ugly but you don't want to hear it, and then you react like you've picked the wrong customers before admitting that you've built the wrong product.

\section{Personal health and well-being, relationships - negative impacts; neglect of personal friend- ships/relationships/leisure}

A relatively minor but frequent theme describes the personal toll that entrepreneurial obsession can take, such as in this example:

Personal sacrifice? Just to put it in perspective, I have no life. On Facebook I'm engaged to my company. No health problems, but I've gained about $40 \mathrm{lbs}$. It's difficult to talk about anything outside the company. No strained relationships because there aren't any.

During Subject G23's "most” entrepreneurial days (first venture), the time and personal commitment required for the business put such a huge strain on his personal relationship (his marriage) that it resulted in a divorce. It also permanently destroyed his relationship with his first partner (his best friend).

\section{Personal characteristics - aggressiveness}

Aggressiveness here is beyond assertive, ambitious self-confidence; it is a conspicuous or even brazen public display of dominant posturing - acts of competitive, territorial cocksureness - possibly blatant threats, or conversely, provocative but productive cage rattling acts suggestive of mania as portrayed in the excerpts below:

Subject G2 learned three very important lessons from this episode. Lesson number one was that regulators are concerned with only two things, keeping their files straight and keeping their jobs. The only way to get their attention is to threaten one or the other.

Scott McNealy encountered heavy criticism during the economic downturn, forcing him to justify his research and development spending as Sun lost market share and prestige. "People have been calling us irrelevant, dead, a zombie, a takeover target, not worth taking over. We've been insulted about every way you can imagine," he said. "All of sudden, we are relevant, we're growing, making money, gaining share." Sun has introduced new products and strategies this year that have generated buzz for a company many thought was on the decline. The resurgence shows why it's best to spend money to develop new products, and why Dell and H-P aren't serious competitive threats, Mr. McNealy said in an interview. Dell has simply proved it knows how to sell computers, he said, and H-P hasn't done enough to innovate. "Everybody who's doing PCs is not in the computer business. They're PC distributors," he said. "The only two computer companies in the PC business are Intel and Microsoft." (Crayton 2004)

While Moore and Noyce were quiet and calm, Grove was volatile. During a business review, Grove would explode, "That's nonsense!" A heated discussion would ensue. The episode would typically end with a thoughtful summary and proposed solution from Moore. 
The review would then proceed until Grove erupted again. Grove would surface the issues (albeit not very diplomatically) that required discussion and could profit from the insights of Moore and Noyce. While no pushovers, Moore and Noyce's style would not necessarily have surfaced the tough issues. The three members of the Office were opposites. Yet they were able to convert their differences into compliments rather than conflicts. Indeed the group regarded conflict to be healthy Grove wrote about "constructive confrontation" as a means to surface tough issues and discuss them from all sides. ( $\mathrm{O}$ 'Toole et al., 2002, pp. 70-71)

\section{Experiencing good fortune - happy accidents; winging it without a plan}

This theme of happy accidents pertains to 'seat-of-the-pants' opportunism when unplanned avenues of commerce just unfold in a surprising sequence of good fortune or less-than-judicious, perhaps slightly manic impulse, as exemplified in the following instances from the data:

My team was part of a smaller subcontractor hired to build hardware. After the original contract ended, I left with the intent to start a company and hire another CEO because I did not have any specific business experience, but I was appointed CEO by the founding team.

Subject G11 reported, "Plans? We started off as a software company and now we build flying cars, equipment boxes for Humvees and diagnostic tools for the B2 bomber. I would say that we adjusted regularly. As we started getting contracts to develop things, customers would come back to us and ask us, 'do you think that you can do this?' and a new business opportunity would be created." "We try to never say 'no' to anyone when they ask us about a project. At the same time we try and capitalize on everything we discover as well. Our proprietary wafers are the result of trying to come up with a lightweight material to build Skyrider with, but it has also become ballistics armour and high strength tool boxes. We also try and capitalize on relationships we already have."

\section{Drive and perseverance - personal ambition, restless, always moving ahead}

The theme of drive and perseverance also encompasses personal ambition, which may indeed serve as the underlying motivator for the entrepreneurial workaholic. Ambition may be about money, pride, ego, fame, and other contributing factors that inspire a subject to foray into entrepreneurship, at times exhibiting a degree of mania. Examples include:

Opportunity comes from a whim or a notion of, "Hey! l'd like to be able to do this." But does anybody else want it, do you care about it enough to make it happen-and make it last? Do you have the passion and the commitment? A startup is like having a child.

Subject G2's old company [that he had been squeezed out of by the VC's board of directors] had gone bankrupt and all of it assets had been sold at auction. An attorney who had done business with that prior company while Subject G2 was still at the helm who knew him personally purchased the name and intellectual property 
of the firm. He then offered to revive the company, provide it with financing, and give Subject G2 a 51\% ownership stake if he would come back and retake the helm. Although flattered by the offer, Subject declined. "It was everything an entrepreneur could ever hope to ask for, but I had moved on from where I was before and that company was in my past."

Imbued with a perception of his own importance on a stage where everything from telephony to music distribution to consumers' relationships with technology is being disrupted, [Steve] Jobs felt there was simply no time to lose. This understanding has fueled the rapid-fire pace of his actions and his obsession with "what's next?" in products (although he would never rush to market a product he thought imperfect). It may have also fed his often harsh, dictatorial, and somehow still-inspiring management style. (Koehn 2009)

Once her revenues reached $\$ 10$ a week, her husband tried to persuade her to slow down. But Madame Walker, as she became known, had bigger ambitions. She set up an office in Pittsburgh, a factory in Indianapolis, and a salon in New York City. She built a sales force of 2,000 mainly black women who were trained in hairdressing and in sales techniques at company-run schools. (Nulty 1992, p. 116)

\section{Drive and perseverance - exaggerated optimism, passion, excitement, loving what they do}

A sense of exaggerated optimism, passion, and excitement for what they do was expressed by many subjects among the data sets, demonstrating an enthusiasm beyond what most people would muster for a work-related proposition, and sometimes exhibiting an appetite for their craft bordering mania. The following instances evince the interpretation of this theme:

An obvious thing to say would be that my best moment was the sale of the company. That was nice, but the best thing was between flop 1 and flop 2-we were going to partner with another group. I had $\$ 20 \mathrm{k}$ left and $\$ 20 \mathrm{k}$ payroll coming up and then the teaming partner sent a letter backing out. My stomach dropped. This was the death knell. I drove home and cried and told no one. After a sleepless night I called a big competitor and their CEO asked how soon could I make a proposal to his Board? I went to California on no sleep for days, but then landed a \$6 M licensing deal which changed everything back to right again. This was the crowning glory-to be out on the edge of the cliff, even to fall-but then I caught a branch on the way down!

He reports that everyone wants to "fly with their own wings" but most people choose not to start a new business because they see obstacles as disadvantages rather than challenges. G12 states that his entrepreneurial spirit is a disease that does not allow him to see the bad side of starting a business. In his own words, "the best way is always the hardest anyway."

Kroc's intense personality and his vision of a national fast-food chain dominated McDonald's from Day One. He was short-tempered, politically conservative, tireless 
and perpetually optimistic. An extraordinary motivator, Kroc fired up his troops with maxim that adorn company bulletin boards to this day. "Free enterprise will work if you will," was a favorite. (Carlson 1989)

All of this has made the industry buzz with speculation that Sun, one of the vendors hardest hit by the dot-com and telecom blowouts, might not make it through the economic downturn. The company's stock price sunk lower and lower, trading below $\$ 3$ last month. But through it all, the irrepressible McNealy has remained confident, and his company has continued to launch new products ... an always-confident McNealy continues to see Sun's cup as half full.

(Montalbano 2002)

Personal health and well-being, relationships - negative impacts; symptoms of anxiety, stress and pressure as part of the job

All data sources confirm the ubiquity of anxiety, stress, and pressure as part of the entrepreneur's job, sometimes taking on manic proportion as evinced in this sampling of incidences:

The contract laws that ultimately resulted in my forced sale and all that was involved was debilitatingly stressful. I don't care to relive the details.

As far back as anyone can remember, Bill McGowan was a workaholic. His workweek was usually seven days, his workday 12 to 15 hours. "I wasn't asleep," he explains now. "What else would I do?" He never exercised. He drank cup after cup of coffee and smoked three packs of Larks a day. (Cook 1987)

\section{Personal characteristics - natural salesperson, ability to sell idea, persuasiveness}

Many subjects exhibit a flair for communicating with enthusiasm their beliefs in their venture propositions and intrinsically recognize the imperative for coalition-building, team-building, and strategic alliances as prelude and in parallel with selling their products or services. The interpretation of this theme is that the entrepreneur foremost is selling himself or herself, then in succession, selling the venture concept, the business relationships, and then finally the business deliverables. Entrepreneurship involves making countless promises: promises to make things happen, promises that plans can be made to work out, promises to solve technical problems, and promises to pay or repay quantities of cash in exchange for the faith in the entrepreneur's ability to deliver on all of these simultaneous promises. Often, the ability to deliver on any one promise is a function of being able to deliver on them all. The venture initiation becomes real when these promises become binding contracts. The system of interdependencies the entrepreneur constructs is also dynamic, comprising many other actors and factors over which the entrepreneur may have little control beyond the power of persuasion - to persuade others to make things go or conversely perhaps to persuade them to sit still and not run off until other things can be made to happen.

Sometimes do these circumstances not only reflect entrepreneurial obsession and mania, but the champion must be as convincing as a clairvoyant oracle. On the subject of salesmanship and the art of persuasion, the Data Book offers a few examples: 
Strategy is selling from optimistic truth; with leadership like a con man-selling the employees, selling the investors, selling the customer-but from the heart like a white knight.

The message is: whatever business you're in, you are selling a service-otherwise it's just another product.

By 1995, Jobs was back in the news with a renewed relationship with Apple. Apple's very existence was in doubt until he persuaded Apple's long-time adversary, Microsoft, and its chairman, Bill Gates, to invest \$150 million in Apple.

(Rogowski and Reilly 2000, p. 662)

In the same way that Henry Ford realized that by keeping selections limited (e.g., color choice: black) he could mass-produce economical cars, Kroc kept the menu simple and the standardization high, to mass-produce economical meals. Each patty, for example, had to weigh exactly 1.6 ounces and be exactly 0.221 inches thick. Manuals documented to the second how to make a shake. Then, through massive advertising, Kroc enticed Americans to recognize their need for his product. As Kroc once cleverly said, "The definition of salesmanship is the gentle art of letting the customer have it your way." (Davids 1999, p. 35)

\section{Actively positioning for opportunity - vision, seeing what others do not see}

Vision is a multi-dimensional theme that encompasses foresight and inspiration, an extrasensory quality that empowers the entrepreneur to perceive deficiencies in technical capabilities, market needs, or possibly both, and to formulate new arrangements of matter, energy, information - molded and enacted via human behaviors and relationships that are not yet scripted - to satisfy the void or simply improve the way the human world works. For many, vision is capricious and arbitrary, a tacit and elusive phenomenon. Others report cultivating and honing a willful prescience through practice. By whichever vision emanates, it impresses a weighty impact on the movements of entrepreneurship and undergirds the notion of clairvoyant oracle. Instances are abundant in all three data sets:

I've always had the opinion that advertising is not the only revenue source on-line. Inspiration came from when I used to be a photographer and couldn't believe how little my work was worth as stock photos. Then at National Geographic I built an extranet and international licensing people started using it for distribution of content to affiliates. But video multimedia starting around 2008, made it crash and there was no system available to solve this problem. No system could handle the streaming and the massive content and the various formats all at once. So I quit that company and set out to build such a system. I spent the next six months getting a team together and started to strategize on how to make it go.

My system was designed to permit project managers in the construction trade to track their field workers' hours and work performance by the workers using their cell phones as mobile data terminals. This was in an era when all the construction workers had begun using cell phones, but there was not a lot of Internet familiarity 
in the trade, and construction managers were not big on computers. This absence of technology seemed particularly prevalent in the niche craft where I started. My system let the field guys punch in a few codes and the office received a consolidated report of everybody's time allocations by jobsite and task.

I had thought that I was selling a product, but when I switched over to a custom service I made an unsalable product worth $\$ 1000$ per custom set!

Growing up in communist regime, Subject G3 longed for being able to practice journalism in a censorship-free environment. This aspiration became possible when he relocated to North America. While screening opportunities, he took notice of the emerging Internet and clearly saw the full potential of this new communication tool. According to G3, the majority of media professionals in mid-1990s considered the Internet 'fourth medium', inferior to TV, radio, and newspaper. G3 on the contrary, regarded the Internet as 'first medium'. The reasons are twofold. First, the Internet not only has the individual power of newspaper, radio, and TV but it also can combine their individual effects-prints, sound and vision - in a single platform. Second, the Internet is superior to these media because it can reach far greater number of people at a relatively low cost. ... One critical factor contributing to G3's company's success is its strategy to preempt and dominate the Internet news service before its competitors. The timing was perfect. When the company was founded, most of its target customers had noticed English on-line news but could not find comparable service in Chinese version.

When McGowan looked at the problem his way-from more than one direction-he noticed two things. First, no one could explain to his satisfaction why AT\&T deserved its long-distance monopoly. "People said AT\&T is so smart and so loved and so big," he recalls. "Or they said that's just the way it is. But I once worked for a railroad that had its own phone system, switchboards and all, so I knew better." Second, he could see that a lean competitor with lower overhead could underprice the giant. (Nulty 1992, p. 112)

But Jobs, the co-founder of Apple Computer Inc., saw with startling clarity something few people realized: Computers would not be confined to the laboratories of government and industry; rather, they would become the stuff of everyday life. $\mathrm{He}$ forced this development relentlessly-sometimes using his boyish charm and sometimes his fury-by developing "friendly" computers that were small, attractive, inexpensive, and easy to use. (Nulty 1992, p. 114)

As one of the most remarkable pioneers in chip technology, Moore has been in the unusual position of defining a law and then making sure it applies. The diminishing size and increasing speed of chips are the driving forces of technological advancement, and Intel, under the leadership of Moore, Robert Noyce and CEO Andy Grove, has changed the focus of buyers from the machine itself to the chip inside. Moore has been at the heart of the new alchemy of computer science for almost four decades, happily admitting he's been at the right place at the right time 
on more than a few occasions. Moore's progress has been prescient to an uncanny degree. (Edwards 1994)

\section{Actively positioning for opportunity - investing personal resources in business idea}

This theme describes the commitment the entrepreneur is willing to submit in terms of personal finances or other resources - to get a concept off the ground, to nourish, and nurture a fledgling enterprise, or perhaps to prove dedicated 'skin in the game' as an appeal to other investors. The illustrative excerpts from the data demonstrate these entrepreneurs' faith in their own sense of clairvoyant oracle:

We had lots of cash flow problems beyond our control, and I had to keep personally investing out of pocket to pay bills.

During expansion phases-hiring and buying stuff before money comes in-it is a little hairy. We have been self-capitalized and bootstrapped, and I've put more in from myself if there were shortfalls. I've taken no outside sources of capital.

The only advice Subject G24 could give to an aspiring entrepreneur about financing is that you will "mind the store" a whole lot better if it is your own money at risk and not someone else's.

McGowan took control of MCI after paying off its debt himself, and for the next two decades he chipped away at AT\&T, first at its control of long-distance service and, when that cracked, at its customer base. He moved MCI to Washington, D.C., all the better to lobby in the halls of government and attack in the federal courts.

(Nulty 1992, p. 112)

\section{Experiencing good fortune - make your own luck; go after it aggressively}

Several subjects recounted more methodical means of encouraging good fortune, whether happy accidents of any description came their way. Rather than wait for some elusive convergence of coincidence and circumstance, which no subjects outwardly advocated, the savvy approach is to plan for potential opportunities and maneuver them into position to elevate the chance of beneficial returns - a calculated gamble on the hunch of a clairvoyant oracle. Several instances are found in the data:

The closest thing to strategic planning we had was that we were opportunistically prepared-we would specifically invest in software or skills for staff even if only vaguely related to things we thought we might like to be able to do-up to a reasonable level-simply so if an opportunity presented itself, someone on staff would know something about that application. We called it 'popcorn software'. It was our primary source of organic growth.

One time I gave my crew a two-day free-for-all to come up with new ideas and recommend changes while the executives were at a conference. This led to the cell phone interface that made the Singapore contract possible. I wish the engineers could often be given more time to just explore, with less pressure to deliver a product and curb costs. 
I am a synergist entrepreneur; I don't go into the lab and invent a new widget. I look for the trends and try to see where there will be a convergence-to look for multiple non-linear advantages and opportunities-that's where you want to be, to make your entrance.

\section{Conclusions}

This research constructs a thematic grounded theory of the technology entrepreneur, specifically looking for - and finding - evidence of the descriptors obsessed maniac and clairvoyant oracle. To investigate our premise, we conducted comprehensive surveys and interviews with 33 founding entrepreneurs, comparatively analyzing their experiences against complementary data sources to develop personal profiles of critical attributes and behavioral characteristics. Employing qualitative analytic techniques, we find the data rich in empirical evidence to support a perspective of entrepreneur as obsessed maniac and clairvoyant oracle, plus many other intrinsic characteristics of personality, motivation, intention, and action that constitute the entrepreneurial actor.

This research has provided an emerging and empirically validated conceptual platform for envisioning and then enacting key constructs of what triggers, catalyzes, and sustains entrepreneurial thought, choice, and action. These constructs are built around the key concepts of strategic knowledge serendipity and arbitrage (also known as $\operatorname{SKARSE}^{\mathrm{TM}}$ ), higher order technological learning, and fractal Mode 3 innovation ecosystems, as well as co-opetition, co-evolution, and co-specialization processes, all helping profile, diagnose, and predict the behavioral attributes of the technology entrepreneur as an obsessed maniac and a clairvoyant oracle.

\section{Methods}

\section{Triangulation of complementary data sources}

Primary data was collected from surveys and interviews with a specifically targeted subject pool of technology entrepreneurs. Supporting data was drawn from a collection of entrepreneurial profiles and interview reports prepared by graduate students in business venturing and entrepreneurship classes, following open-ended templates of suggested interview topics. Literature review data was drawn from published sources: biographical and historical accounts of publicly known entrepreneurial individuals obtained by extensive library research.

\section{Data inclusion criteria}

In each of the three data sources, data records have been compiled to represent some aspect or aspects of the nature, actions, or experiences of a subject technology entrepreneur, the entrepreneur reflecting the unit of analysis of this study. Only data records that meet the following inclusion criteria were retained:

1. Subject must be or must have been a technology entrepreneur. For the purpose of this study, technology entrepreneur is defined as a principal actor in the founding of at least one technology-driven or technology-based business venture, whether or not the venture(s) persisted as going concern(s). 
2. For the definition of this research, technology venturing involves the creation or implementation of new technology-driven or technology-based for-profit business organizations.

(a) In technology-driven businesses, the profit is fully dependent on the creation or implementation of new technology (Sipp 2011) or innovations in the use or deployment of existing technology. Technology-driven firms compete to produce the technologies to sustain and advance their customers (supply side) (Carayannis and Formica 2008). In this latter perspective, the term 'supply side' denotes that the firm operates on the supply side of commerce - developing, implementing, and selling technology.

(b)In a technology-based business, the profit is enabled and supported by technology, but technology itself is not necessarily the product, service, or experience being sold (Sipp 2011). Technology-based firms depend on the adoption and use of technologies produced by other firms (demand side) (Carayannis and Formica 2008). In this latter perspective, the term 'demand side' denotes that the firm operates on the demand side of commerce - buying, adopting, and utilizing technology.

3. For the definition of this research, entrepreneurship entails all phases of conception, planning, implementation and startup.

\section{Data exclusion criteria}

Data records that meet the following exclusion criteria were rejected as null:

1. Franchisees who are not really entrepreneurs but contract to an existing business formula.

2. Entrepreneurs who have launched startups based on non-technological goods or services or pre-established technology-neutral markets and technology-neutral deployments and delivery mechanisms.

3. Inventors and self-employed operators who have not founded a formal business entity and attempted to bring a venture conception to market.

4. Self-employed professional practitioners (e.g., doctors, dentists, management consultants, caterers, decorators, etc.) unless they have established their enterprise with a competitively differentiating technological innovation.

\section{Data collection procedure}

Open-ended interviews were conducted under confidentiality agreements with 33 technology entrepreneurs vetted against the above criteria. Four of the subjects were serial entrepreneurs who reported multiple ventures, for a total of 38 ventures. Of this primary subject pool, interview questions (a) through (j) were asked as follows.

a) Would you be willing to describe in depth your experiences that led you to give your answer to [specific question(s) asked in the foregoing EPS Form (1) through (15)]?

b) With respect to your reported experiences, how do you define success and failure? What are the characteristics of outcomes that you see as unacceptable in terms of what you originally set out to accomplish vs. what really unfolded? 
c) Can you recall examples of intentional strategic preparation and planning and in terms of people, connections, knowledge, processes, or any other factors that impacted the course of your business venturing?

d) Can you recall examples of unexpected 'happy accidents' in terms of people, connections, knowledge, processes, or any other factors that impacted the course of your business venturing?

e) How much of your specific experience in this venture seemed like it was excessively beyond your control? Which parts and in what ways?

f) Were there instances when try as you might, you simply could not make things happen the way you thought they should?

g) Were you ever driven to drastically alter or compromise your plans, your perspective, your standards, or your commitments in the name of the larger mission and would you be willing to share examples? Anything illegal/unethical/or even just bothered your conscience? How were you cheated?

h) Are you willing to relate the gaps or 'white space' in your target market and comment on the validity of your expectations, and elaborate on how the venture development played out, with what adjustments?

i) In terms of both your positive motivations and determination to surmount obstacles, could you elaborate on your persistence and drive? Were there personal sacrifices, and if so, of what nature? Were you able to accomplish what you set out to do? Any damaged relationships, personal regrets, health problems?

j) What do you recall most favorably about your entrepreneurial experience? Was it worth it? Would you do it again?

On the whole, subjects were very willing to candidly discuss their experiences. Although no subjects dropped out mid-interview; a very small number simply declined to respond to certain lines of inquiry, but it was much more often the case that a subject would spontaneously reveal private facts without prompting. All interviews were transcribed to wordprocessed files as originally recorded, then verified by a separate proofreader.

The contributed reports from graduate students covered 26 technology entrepreneurs, vetted against the same criteria for inclusion or exclusion, containing narrative responses to elements of this template:

a) Historical background of founding entrepreneur and of entrepreneurial venture what were the overarching motivations and trigger events along with any long term planning - what were the facilitating and the impeding elements?

b) Business plan development, idea screening and opportunity recognition, including evaluation of alternative ventures and business ventures.

c) Analysis of sources of venture financing (personal/family funds - friends, family and fools, angels, venture capital, strategic alliances, SBIR/SBDC funds, other private/ public funds) - what worked for the entrepreneur or not, why, how, and when?

d) Analysis of essential venture business functions - marketing, finance, manufacturing, brand management, fund raising, customer management, employee recruitment, training, and retention, competitive intelligence, strategic alliances, etc. 
e) Lessons learned and critical success/failure factors in venture initiation and development - would the entrepreneur do it again and in the same way or differently - when, how, why, with whom, for whom?

f) Other pertinent venture lifecycle issues per the entrepreneur's perspective.

g) Other issues at the heart of the matter - what insights do the entrepreneur volunteer unasked - what might be considered surprising?

The biographical data consisted of 64 compact published articles from library sources covering 20 technology entrepreneurs, vetted against the same criteria for inclusion or exclusion.

\section{Data processing methodology}

The specific methodology for processing the data from this point was as follows:

1. The researcher visually parsed each word-processed interview transcript, narrative report, and biographical article to flag key points of data and information, and to develop categorical codes from the words and concepts found within the data text (thematic coding).

2. The researcher interpreted the flagged findings to develop a Code Book of the terms that emerged from the patterns and themes found in the data text, handling words and passages carefully to organize the data into conceptual categories, not to impose categorical expectations on the data. Ely defines themes to be one of these two instances:

1) A statement of meaning that runs through all or most pertinent data.

2) One in the minority that carries heavy emotional or factual impact.

3. Working back and forth between the coded text excerpts and the concept dictionary, the researcher consolidated thematically comparable passages from the data into the resultant categories, grouping the excerpts to produce tables of evidentiary text in a Data Book that supports the thematic categorizations (thematic analysis).

4. The researcher performed cognitive, interpretive assessment and evaluation of findings to formulate inductively the interpreted insights by comparing and contrasting the multi-dimensional factors of the 33 different primary subject profiles, 26 supporting subject profiles, and 20 biographical subject profiles (grounded theory-building). targeted the preliminary pool of live entrepreneurial subjects, enabled access to the GEFRI interview archives, and provided technical and editorial guidance. MRS authored the background and summary literature review, parsed and compiled the entrepreneurial profile data from previously published sources, vetted and abstracted the entrepreneurial profile data from the GEFRI interview collection, contacted and interviewed the live entrepreneurial subjects and transcribed the data from those sources, subselected and catalogued the thematic coding from all data sources, and consolidated the aggregated findings. Both authors read and approved the final manuscript. 


\section{References}

Afuah, A. (2003). Innovation management: Strategies, implementation, and profits. New York: Oxford University Press.

Carayannis, EG. (1992). An integrative framework of strategic decision making paradigms and their empirical validity: The case for strategic or active incrementalism and the import of tacit technological learning (RPI School of Management Working Paper Series No. 131). Troy, NY: Rensselaer Polytechnic Institute.

Carayannis, EG. (1993). Incrementalisme strategique. Le Progrès Technique, 93(2), i-vi.

Carayannis, EG. (1994a). A multi-national, resource-based view of training and development and the strategic management of technological learning: Keys for social and corporate survival and success. Strasbourg, France: Paper presented at 39 International Council of Small Business Annual World Conference.

Carayannis, EG. (1994b). The strategic management of technological learning: Transnational decision-making frameworks and their empirical effectiveness. Dissertation Abstracts International, 55(11), 3564.

Carayannis, EG. (1994c). Gestion strategique de l'acquisition des savoir-faire. Le Progrès Technique, 94(1), 37-39.

Carayannis, EG. (1998). Higher order technological learning as determinant of market success in the multimedia arena; a success story, a failure, and a question mark: Agfa/Bayer AG, Enable Software, and Sun Microsystems. Technovation, 18(10), 639-653.

Carayannis, EG. (1999a). Knowledge transfer through technological hyperlearning in five industries. Technovation, 19(3), 141-161.

Carayannis, EG. (1999b). Fostering synergies between information technology and managerial and organizational cognition: The role of knowledge management. Technovation, 19(4), 219-231.

Carayannis, EG. (2000a). Investigation and validation of technological learning versus market performance. Technovation, 20(7), 389-400.

Carayannis, EG. (2000b). The strategic management of technological learning. Boca Raton, FL: CRC Press.

Carayannis, EG. (2001). The strategic management of technological learning: Learning to learn-how-to-learn in high tech firms and its impact on the strategic management of knowledge, innovation and creativity within and across firms. Boca Raton, FL: CRC Press.

Carayannis, EG. (2004). Measuring intangibles: Managing intangibles for tangible outcomes in research and innovation. International Journal of Nuclear Knowledge Management, 1(1/2), 49-67.

Carayannis, EG. (2008a). Knowledge-driven creative destruction, or leveraging knowledge for competitive advantage: Strategic knowledge arbitrage and serendipity as real options drivers triggered by co-opetition, co-evolution and co-specialization. Industry and Higher Education, 22(6), 343-353.

Carayannis, EG. (2008b). Conceptual framework for an analysis of diversity and heterogeneity in the knowledge economy and society. In EG Carayannis, A Kaloudis, \& $\AA$ Mariussen (Eds.), Diversity in the knowledge economy and society: Heterogeneity, innovation and entrepreneurship (Ch. 5, pp. 95-116). Cheltenham, UK: Edward Elgar Publishing, Incorporated.

Carayannis, EG. (2009). Firm evolution dynamics: Towards sustainable entrepreneurship and robust competitiveness in the knowledge economy and society. International Journal of Innovation and Regional Development, 1(3), 235-254.

Carayannis, EG. (2012). Strategic Knowledge Arbitrage and Serendipity (SKARSE) in action. NVTC Magazine, Winter 2013, 34-35.

Carayannis, EG, \& Alexander, J. (1999). Winning by co-opeting in strategic government-university-industry (GUI) partnerships: The power of complex, dynamic knowledge networks. Journal of Technology Transfer, 24(2/3), 197-210.

Carayannis, EG, \& Alexander, J. (2002). Is technological learning a firm core competence; when, how, and why: a longitudinal, multi-industry study of firm technological learning and market performance. Technovation, 22(10), 625-643.

Carayannis, EG, \& Alexander, J. (2004). Strategy, structure and performance issues of pre-competitive R\&D consortia: Insights and lessons learned from SEMATECH. IEEE Transactions of Engineering Management, 51(2), 226-232.

Carayannis, EG, \& Campbell, DFJ (Eds.). (2006). Knowledge creation, diffusion, and use in innovation networks and knowledge clusters: A comparative systems approach across the United States, Europe, and Asia. Westport, CT: Praeger Publishers.

Carayannis, EG, \& Campbell, DFJ. (2009). 'Mode 3' and 'Quadruple Helix': Toward a 21st century fractal innovation ecosystem. International Journal of Technology Management, 46(3/4), 201-234.

Carayannis, EG, \& Chanaron, JJ (Eds.). (2007). Leading and managing creators, inventors, and innovators: The art, science, and craft of fostering creativity, triggering invention, and catalyzing innovation. Westport, CT: Greenwood Publishing Group.

Carayannis, EG, \& Formica, P (Eds.). (2008). Knowledge matters: Technology, innovation and entrepreneurship in innovation networks and knowledge clusters. London: Palgrave Macmillan.

Carayannis, EG, \& Gonzalez, E. (2003). Creativity and innovation = competitiveness? When, how, and why. In LV Shavinina (Ed.), International handbook on innovation (Part VIII, Ch. 3, pp. 587-606). Oxford, UK: Elsevier Press.

Carayannis, EG, \& Juneau, T. (2003). Idea makers and idea brokers in high-Technology Entrepreneurship: Fee vs. equity compensation for intellectual venture capitalists. Westport, CT: Praeger Publishers.

Carayannis, EG, \& Kaloudis, A. (2008). Diversity in the knowledge economy and society: heterogeneity, innovation and entrepreneurship. UK: Edward Elgar Publishing, Incorporated.

Carayannis, EG, \& Provance, M. (2007). Measuring firm innovativeness: towards a composite innovation index built on firm innovative posture, propensity and performance attributes. International Journal of Innovation and Regional Development, 1(1), 90-107.

Carayannis, EG, \& Sipp, CM. (2006). e-Development towards the knowledge economy: Leveraging technology, innovation and entrepreneurship for smart development. London: Palgrave Macmillan.

Carayannis, EG, \& Sipp, C. (2010). Why, when, and how are real options used in strategic technology venturing? Journal of The Knowledge Economy, 1(2), 70-85.

Carayannis, EG, \& von Zedtwitz, M. (2005). Architecting gloCal (global-local), real-virtual incubator networks (G-RVINs) as catalysts and accelerators of entrepreneurship in transitioning and developing economies: Lessons learned and best practices from current development and business incubation practices. Technovation, 25(2), 95-110.

Carayannis, EG, \& Ziemnowicz, C. (2007). Re-discovering Schumpeter: creative destruction evolving into 'Mode 3'. London: Palgrave Macmillan. 
Carayannis, EG, Rogers, EM, Kurihara, K, \& Allbritton, MM. (1998). High-technology spin-offs from government R\&D laboratories and research universities. Technovation, 18(1), 1-11.

Carayannis, EG, Evans, D, \& Hanson, M. (2003). A cross-cultural learning strategy for entrepreneurship education: Outline of key concepts and lessons learned from a comparative study of entrepreneurship students in France and the US. Technovation, 23(9), 757-771.

Carayannis, EG, Popescu, D, Sipp, CM, \& Stewart, MR. (2006). Technological learning for entrepreneurial development (TL4ED) in the knowledge economy (KE): case studies and lessons learned. Technovation, 26(4), 419-443.

Carayannis, EG, Ziemnowicz, C, \& Spillan, JE. (2007). Economics and Joseph Schumpeter's theory of creative destruction: Definition of terms. In EG Carayannis \& C Ziemnowicz (Eds.), Re-discovering Schumpeter: Creative destruction evolving into 'Mode 3' (pp. 23-45). London: Palgrave Macmillan.

Carayannis, EG, Provance, M, \& Givens, N. (2011). Knowledge arbitrage, serendipity and acquisition formality: Their effects on sustainable entrepreneurial activity in regions. IEEE Transactions in Engineering Management, 58(3), 564-577.

Carlson, E. (1989). American entrepreneurs: McDonald's Kroc bloomed late but brilliantly. Wall Street Journal (Eastern edition), p. 1. New York: Dow Jones \& Company, Inc.

Cook, WJ. (1987). The CEO who got a new heart. US News \& World Report, 103(16), 60.

Crayton, H. (2004). Sun Microsystems CEO says rivals are merely distributors. The Dallas Morning News, 1.

Davids, M. (1999). Ray Kroc (1902-1984): Flipping over efficiency. The Journal of Business Strategy, 20(5), 34-35.

Drucker, PF. (1985). Innovation and entrepreneurship. New York: Harper \& Row Publishers, Inc.

Edwards, O. (1994). Gordon Moore. Forbes, 154(13), 158-159.

Florida, RL, \& Kenney, M. (1990). The breakthrough illusion: Corporate America's failure to move from innovation to mass production. New York: Basic Books.

Hindle, B, \& Lubar, SD. (1986). Engines of change: The American industrial revolution, 1790-1860. Washington, DC: Smithsonian Institution Press.

Kline, SJ, \& Rosenberg, N. (1986). An overview of innovation. In R Landau \& N Rosenberg (Eds.), The Positive-Sum Strategy (pp. 275-305). Washington, DC: The National Academy Press.

Koehn, N. (2009). His legacy. Fortune, 160(10), 110.

Montalbano, E. (2002). 2002 top 25 executives: Scott McNealy. CRN, 1021, 104-0105.

Nulty, P. (1992). The national business hall of fame. Fortune, 125(6), 112-118.

O'Toole, J, Galbraith, J, \& Lawler, EE, III. (2002). When two (or more) heads are better than one: The promise and pitfalls of shared leadership. California Management Review, 44(4), 65-83.

Rogowski, SJ, \& Reilly, ED. (2000). Encyclopedia of Computer Science (4th ed.). Chichester, UK: John Wiley and Sons Ltd.

Schumpeter, JA. (1942). Capitalism, socialism and democracy. New York: Harper and Brothers.

Sipp, CM. (2011). Why, when and how are real options used in strategic technology venturing? The George Washington University, ProQuest, UMI Dissertations Publishing. 3450568.

Stewart, MR. (2011). Technology entrepreneurship: a deliberation on success and failure in technology venturing toward a grounded theory of dystechnia. The George Washington University, ProQuest, UMI Dissertations Publishing. 3450928

doi:10.1186/2192-5372-2-2

Cite this article as: Carayannis and Stewart: Obsessed maniacs and clairvoyant oracles: empirically validated patterns of entrepreneurial behavior. Journal of Innovation and Entrepreneurship 2013 2:2.

\section{Submit your manuscript to a SpringerOpen ${ }^{\circ}$} journal and benefit from:

- Convenient online submission

- Rigorous peer review

- Immediate publication on acceptance

- Open access: articles freely available online

- High visibility within the field

- Retaining the copyright to your article

Submit your next manuscript at $\boldsymbol{\sim}$ springeropen.com 